Marine Geophysical Researches

June 2005; 26(2-4) : 235 - 245

http://dx.doi.org/10.1007/s11001-005-3721-x

(c) Springer 2005
Archimer, archive institutionnelle de l'Ifremer http://www.ifremer.fr/docelec/

\title{
Seistec Seismic Profiles: A Tool to Differentiate Gas Signatures
}

\author{
A. Baltzer ${ }^{1, *}$, B. Tessier $^{1}$, H. Nouzé ${ }^{2}$, R. Bates ${ }^{3}$, C. Moore ${ }^{4}$ and D. Menier ${ }^{5}$
}

(1) Laboratoire de Morphodynamique Continentale et Côtière-UMR 6143, Université de Caen, 24 Rue des Tilleuls, 14000 Caen, France

(2) IFREMER Brest, DRO/GM, France

(3) School of Geography and Geosciences, University of St Andrews, Scotland, UK

(4) Department of Biological Sciences, Herriot Watt University, Scotland, UK

(5) Laubs, Université de Bretagne Sud, Vannes, France

\author{
*: Corresponding author : Email: baltzer@geos.unicaen.fr \\ Phone: +33-0-231-565745 \\ Fax: +33-0-231-565-757
}

\begin{abstract}
The presence of gas is a common feature in many seismic sections. However, the origin of the gas is often difficult to determine. Recently acquired very high resolution seismic profiles using an IKB Seistec boomer provide useful insight to the understanding of the gas origins in a range of environmental settings including sea lochs and coastal lagoons. The gas features are described both from a qualitative point of view through their acoustic facies, and quantitatively through the associated seismic signal (polarisation, amplitude). Acoustic facies include acoustic turbidity, gas "curtains" and "blankets" as well as "white fringes" and "black shadows". All the features encountered have been related to specific gas nature generated by different sources (organic matter degradation in paleovalley infillings, waste material effluent).
\end{abstract}

Keywords: Seistec profiles - acoustic facies - gas - signal polarisation - signal amplitude 


\section{Introduction :}

Gas in seafloor sediments has been recognized for a number of years (Emery \& Hoggan, 1958; Hovland and Judd, 1988) and continues to be actively studied (Garcia-Gil et al., 2002; Missiaen et al., 2002. In shallow sediments, gas occurence is often associated with an acoustic turbidity phenomenon, particularly in association with soft sediments resulting in an almost total blanking of the underlying geological structure (Taylor, 1992 ; Missiaen et al., 2002 ; Gorgas et al., 2003). Gas charged sediments are manifest in seismic data by an abrupt decrease of acoustic velocity combined with a strong ringing or reverberation accompanied by a decrease in the amplitude of full waveforms that is not observed in gas-free sediments (Gorgas et al., 2003). The abundance of free gas bubbles in the sediment is controlled by temperature, salinity and pressure which in turn control bioactivity and chemical processes within the water and sediment column (Wever \& Fiedler, 1995). Two potential origins have been postulated, namely gas derived from organic material, with the biogenic process relying on bacterial activity, or gas derived from thermogenic methane at depths greater than $1000 \mathrm{~m}$ (Davis, 1992).Despite these observations on the occurrence of gas, the origin of the gas remains difficult to define on seismic data.

In the framework of several projects dealing with recent nearshore sediment Holocene infillings and wedges, very high resolution seismic data have been acquired in different environmental settings (fig. 1) such as lochs (e. g. Creran and Sunart Lochs, west coast of Scotland) and lagoons (e.g. Leucate and Thau Lagoons, Mediterranean Sea). In all cases, despite differing geological and climate context, seismic signatures reflecting the occurrence of gas in shallow sediment layers have been found. Typical gas-related seismic signatures, similar to those reported in the literature, include acoustic blankets, acoustic curtains, acoustic plumes† (Taylor, 1992; GarciaGil et al., 2002) and acoustic turbidity (Hovland \& Judd, 1988) (fig. 2). Gas curtains and gas blancket are characterised by a similar dark and diffuse buried facies, topped by a clear horizontal limit and abrupt lateral facies changes (fig. 2). The main difference between these two facies consists in shorter extension for the curtain facies. Two additional signatures were also recognized: the "black shadow" and the "white fringe" facies. The black shadow facies differs from the gas curtain facies as it reaches the sea floor (not buried) (fig. 2). The white fringe facies appears very different, as its top limit follows the seafloor morphology (fig. 3C).

For each case study, the gas-related acoustic facies is characterized by a particular seismic signature.

This paper presents three of these characteristic seismic gas facies, the blanket facies, the white fringe and the black shadow facies, identified from signal analysis. We show that the seismic 
signal shape and geometry, can provide important clues about the gas origin.

\section{Seismic data acquisition}

All the data presented in this paper have been acquired using the boomer based IKB-Seistec profiler (Simpkin \& Davis, 1993). This profiler has been designed specifically for collecting very high-resolution data in shallow water environments but can be used as well in water depth > 200m (Simpkin \& Davis, 1993; Mosher \& Simpkin, 1999). The Seistec profiler comprises a 2.5 $\mathrm{m}$ long catamaran supporting both the boomer source and receiver. The source is an IKB model B3 wide band electrodynamic "Boomer" producing a single positive peak pressure impulse with a peak pressure of $5 \times 10^{10} \mu \mathrm{Pa}$ measured on-axis and referred to a distance of $1 \mathrm{~m}(214 \mathrm{~dB} / / 1 \mu \mathrm{Pa}$ @ $1 \mathrm{~m}$ ) with a pulse duration in the range from 90 to $200 \mu \mathrm{s}$. This is very important as the narrower a pulse is, the broader (or wider) the band of frequencies that exist. So to be able to resolve two close spaced reflectors, it is necessary to have a narrow pulse so that the echoes separate sufficiently. Thus a narrow pulse width which possesses a wide frequency band is essential. That means it is bandwidth and not frequency that determines resolution.The receiver is a line-in-cone receiver located adjacent to the boomer plate $(70 \mathrm{~cm})$. The source emits useful frequencies in the range $1-10 \mathrm{kHz}$ and gives a resolution down to $25 \mathrm{~cm}$. Penetration is up to 100 $\mathrm{m}$ in soft sediments, and $200 \mathrm{~m}$ in deep water soft sediments. As we used the signal processed outpout from the SPA3 (the signal conditioning unit) for digitization, the high cut is reduced to 10 Khz.

During the surveys, carried out on board of small boats at a speed of about 3 knots, a SIG Energos power supply was used with a power of 50, 100 or $200 \mathrm{~J}$ (mainly $100 \mathrm{~J}$ ) and a shooting rate of $2 \nmid$ shots/s. The seismic data were recorded with an Elics-Delph digital acquisition system with 4000 bits per sample, a sampling frequency of $20 \mathrm{kHz}$ and a recording length of $200 \mathrm{~ms}$. The position was determined by a differential GPS directly connected to the Delph.

The exceptional time resolution and the fixed source-receiver geometry of the Seistec profiling system, together with its high sub-bottom penetration, allow a quantitative analysis of the different seismic signature shapes and geometries and signal amplitudes.

\section{Seismic processing}

Signal processing, including signal polarity and relative amplitude analysis were performed using the SithËre-Sisbise software, developed at IFREMER, for all the main reflectors along the seismic lines. 


\section{Seismic polarisation analysis}

A reflector with a reversed polarity (or phase inversion) indicates a sediment layer of higher acoustic impedance overlying a sediment layer of lower acoustic impedance. Since acoustic impedance is a product of sound speed and density, such a reflector implies a decrease in P-wave velocity or/and in bulk density which can generally be attributed to gas occurrence.

Since the data were digitally recorded, it was possible to study the raw signal (unfiltered or stacked) and to access the original phase of the signal. Thus, signal polarisation analysis of the recorded signals was conducted for several survey cases. This analysis involved comparing the phase of the sea-floor signal with the phase of the "selected" (presumably gassy) reflector signal. As the seafloor signal is assumed to be characterised by a "normal polarisation", due to the positive water/sediment impedance contrast (fig. 4), a phase inversion (reversed polarity) reveals a negative contrast, which in turn indicates possible presence of gas. Numerous signal analyses were conducted along the profiles but for presentation reasons we will only discuss a single shot signal (fig. 4), chosen as the most representative sampled signal for the facies.

It must be noted that the source signal could be slightly different for each shot. However, for a single shot, it is considered that the comparison of the phase between two different reflectors is valid (Nouzé and Baltzer, 2003). As the frequency band of the data is between 2.5 and $6.0 \mathrm{kHz}$, at a $20 \mathrm{kHz}$ sampling frequency, this means there are about 4 data points per cycle. Thus, a visual examination of the signal polarity seems valid (even though some signals are truncated).

The Sithère software enables the selection of the seafloor reflector signal, and the gas reflector signal, along a vertical axis (a single shot) together with a visualisation of the appropriate phases (fig. 4). The signal and phase inversion can be clearly observed for each case. Amplitudes given here are normalised and thus represent a relative amplitude value. To obtain a reliable amplitude value, additional software was developed (Sisbise) providing another amplitude analysis, based on extraction of the instantaneous amplitude.

\section{Seismic amplitude analysis}

The instantaneous amplitude of the signal was analysed for selected reflections on each seismic profile. After geometrical attenuation correction, the amplitudes provide information about the relative reflectivity of the interface responsible for each reflection. The relative reflectivity is then plotted along each profile.

Along any reflecting horizon, two analyses are performed:

1/ Amplitude analysis was made by extracting the maximum value of the instantaneous amplitude of the signal for a given reflector. Low sampling frequency with respect to the central frequency 
of the signal might lead to underestimation of the amplitude values: peaks of the signal might not be properly sampled. Computing the instantaneous amplitude of the signal lowers the frequency content of the signal and minimizes this problem. No examples of these analysis are presented here, as we were confronted to the irregular (non continuous) aspect of the gas reflector. Thus, we preferred the second method, described below.

2/ Where gas occurs in the sediments, the signal is diffracted and there is no single reflector that can be easily followed. In such a case, in order to get a representative value of the strength of a given reflector, an average of the instantaneous amplitude over a time window was computed. This average can be regarded as a numerical value representative of the "darkness" of the seismic section on a narrow band along the reflector. This second method offered the possibility to determine the acoustic areas characterised by a facies of acoustic turbidity (no continous top reflector) and to quantify the signal amplitude (figs. 5 \& 6). Thus, amplitude values were integrated between $+0.5 \mathrm{~ms}$ above the selected reflector to $-2 \mathrm{~ms}$ below it in order to obtain an integrated instantaneous amplitude value .

\section{Case histories}

Infilling sequences of Leucate and Thau Lagoons (Gulf of Lyon, France) and Lochs Creran and Sunart (Scotland)

Figures 3A \& 3B show different Seistec profiles marked by characteristic facies associated with gas occurrence. These facies include the following:

- acoustic turbidity facies in Leucate and Thau lagoons,

- gas curtain facies in Loch Creran,

- gas blanket facies in Loch Sunart.

The Leucate and Thau lagoons are part of a lagoonal system located on the Rhone Delta, Western Gulf of Lions, near the border with Spain (fig. 1). These lagoons are separated and protected from the sea by sandy barriers, or lidos, and are characterised by very shallow waters from 2 to $5 \mathrm{~m}$ water depth. Most lagoons of the system started to infill around 6000 years BP as sea level stabilized and the lido could settle. The infilling of the lagoons reflect the progressive closure by the barriers and is typically composed of alternative deposits of lagoonal clays and marine sands. The acoustic turbidity reaches up to the sea floor but appears to be diffuse. The often sharp lateral contact with the gas-free sediments appears to correspond with a greater thickness of sediment infill of the lagoonal depression. The result is that gassy sediments predominantly occupy the deeper part of the channels. Signal analysis was unsuccessful on these data because of the diffuse 
aspect of the sea floor.

Loch Creran and Loch Sunart are situated on the west coast of Scotland, north of Oban (fig.1). They are typical of fjord style sea lochs with large water depth variations and narrow, steep sides. The gas curtain facies observed in Loch Creran (fig. 3B) is marked by a diapiric shape. The occurrence of this facies coincides with the buried valley axis which is draped by a stratified sequence and buried below a thick transparent unit. Gas blanket facies is observed in many places at Loch Sunart (figs 3B, 4A, 6). It is similar to the gas curtain facies except that it extends laterally over a much greater distance. This acoustic facies was observed by Taylor (1992) where very sharp contacts exist with the overlying sediments. Seismic polarisation analysis of the gas blanket facies in Loch Sunart shows a gas blanket with relative amplitudes varying from -500 to 1000 for the seafloor reflector (fig. 4A). Although this seafloor reflector appears discontinuous, the signal (note the phase) shows an important positive peak (amplitude of 950) between two negative peaks, which is typical of bottom reflectors (see also fig. 4C). The gas reflector shows very high amplitude values (from -1500 to 1500) and is characterised by a phase inversion confirming the presence of gas.

The signal of the gas reflector is diffracted and there is no single reflector that can be easily followed. In order to obtain a representative value of the strength of this reflector an average of the instantaneous amplitude over a time window ( $+0.5 \mathrm{~ms}$ above the selected reflector and $2 \mathrm{~ms}$ below it) was computed. Figures $5 \& 6$ show the integrated amplitude data along two profiles in Loch Sunart and Loch Creran, revealing amplitude values for the gas reflector varying from 100 to 300. Note that in these examples seismic amplitude analysis was able to distinguish between the morainal seismic facies, characterised by high amplitude values (from 400 to 700), and the gas facies showing lower amplitude values $(<300)$.

\section{White fringe facies in Loch Sunart}

Seistec profiles acquired in the relatively deep parts of Loch Sunart between 40 and $50 \mathrm{~m}$ water depth, show a facies that is characterised by a transparent fringe overlying an acoustically turbid facies (fig. 3C). This facies is marked by a relatively constant thickness of about $1.3 \mathrm{~m}$, except on its extremities . No clear reflector delineates the top of the acoustically turbid facies.

The polarisation analysis reveals a seafloor signal with relative amplitude values from -500 to 500 (fig. 4B). The continuous, dark bottom reflector corresponds to a signal with a first important negative peak, between two small positive peaks. This bottom signal appears different from the bottom signals observed in figs. 4A \& 4C, which may suggest an important water content of the superficial sediments (NouzÈ \& Baltzer, 2003). 
The gas reflector corresponding to the white fringe facies shows relative values ranging from 1200 to 700, with no clear phase inversion, but with a typical signature of acoustic turbidity (chaotic reflection) (fig. 4B). These relative amplitude values are two times less than the relative amplitudes observed in the gas blanket facies (fig. 4A).

No integrated instantaneous amplitude analysis was conducted in this case because of the irregular morphology of this facies which did not allow a clear definition of the time window.

\section{Black shadow facies in Loch Creran}

Loch Creran contains several fish farms that emit waste material into the loch close to the area where seismic profiles were acquired. At theses locations, a unique phenomenan is observed on the seismic profiles: a very dark facies with distinct multiple reflections (figs. 2, 4C and 5). The lateral extent of this facies is about $300 \mathrm{~m}$ and the lateral boundaries are abrupt.

The signal polarisation analysis shows very high relative amplitude values (from - 60000 to 60 000) with no underlying reflectors (fig. 4C). All of the signal energy seems to be reflected by the surficial sediments.

Taken from the same time window, the seismic amplitude analysis reveals extremely high values of the integrated instantaneous amplitudes ranging from 1000 to 1600 (fig. 5). Such large values are not observed in any of the previous cases, even for morainal facies or rocky outcrops.

\section{Discussion}

Acoustic turbidity, gas blanket and gas curtain facies in Lagoons of Leucate and Thau (Gulf of Lyon, France) and Lochs Creran and Sunart†(Scotland)

Results of the signal analysis show that the facies of the gas blanket and gas curtain are characterised by:

- a relative seafloor amplitude from -500 to 1000 with a first significant positive peak (fig. 4A)

- a strong relative gas reflector amplitude from -1500 to 1500 (fig. 4A)

- a phase inversion for the gas reflector (fig. 4A)

- an integrated gas reflector amplitude varying from 100 to 400 (fig. 5 \& 6)

Gas blanket and gas curtain facies were observed in Loch Creran and Loch Sunart (fig. 3B), only when a suffisant thickness of sediments is reached†above a rich organic sedimentary deposit usually in valley bottoms or depressions. Thus, blanket and curtain facies do appear only where 
the sediment infilling is the most important (pressure conditions), and usually not on the sides of the depressions. Similar observations were made for the acoustic turbidity facies in Thau and Leucate lagoons: acoustic turbidity facies occurs within the deeper part of the lagoons: they correspond to the thickest part of the infilling sequences.These observations agree with those made by Taylor (1992) where the occurrence of gas curtains (100 to $500 \mathrm{~m}$ of lateral extension) and gas blankets (> $500 \mathrm{~m}$ of lateral extension) in the Firth of Forth was also linked to thicker accumulations of sediment in the centre of channels. But for Loch Sunart, the phase inversion observed at the top of the gas blanket seems to suggest that the quantity of gas contained in the sediments is larger compared to Taylor's observations.

According to Taylor (1992), the mode of formation of gas curtains could be a combination of biogenic factors (deposition of organic matter in the channels) and thermogenic factors (through structural joints and faults) as the Firth of Forth and the river Clyde are situated along a major fault.In most of our examples,Thau and Leucate lagoons, the eastern parts of Loch Creran and Sunart, the gas likely has a biogenic origin resulting from the decay of organic matter in shallow waters and confined areas. For the deeper part of Loch Sunart (still very confined and narrow sides), the seismic data do not seem to give any evidence of faulting (even on neighbour profiles) and the geological map of this area doesn't show any fault going along the lochs in these places. Thus it could not be exluded as faults exist in all this area, but lochs are different from rivers systems, and so do not follow pre-existing fault pattern: the faults occuring in Loch Sunart and Loch Creran are faults perpendicular to the main lochs axis, and don't seem to influence the spatial repartition of the gas blanket and gas curtain facies.

It is postulated that the gas blanket at Loch Sunart is just another expression of acoustic turbidity, but here it is sealed by an impermeable layer. Most likely the acoustic turbidity, gas curtains and gas blankets observed here are a similar expression of the occurrence of biogenic gas, derived from the deposition and decay of organic material on the bottom of buried depressions or valleys. The difference between the acoustic turbidity facies on one hand and the curtain and blanket facies seems to be the amount of gas content. Gas curtains and gas blankets facies seem to be marked by a higher gas content. These facies represent the sub surface tracers, footprints of buried channels and depressions.

\section{White fringe facies in Loch Sunart}

This facies is characterised by:

- a relative low amplitude of the sea floor reflector† $(<500)$ with a first negative peak (fig. 4B) 
- a relative amplitude value of the gas reflector from -1000 to 800

- a constant thickness (except at the edges) of non-gassy sediments at the top of the sedimentary column, whatever the morphology or water depth.

The white fringe facies seems to appear only in near-surface unconsolidated sediment bodies (the transparent body was sampled by a $2 \mathrm{~m}$ length core) with high water content, such as valley deposits and drifts within the loch. This observation is in good correlation with the low amplitude of the bottom reflector and a first negative peak of the signal, typically for unconsolidated sediments. The acoustic facies appears like an "infilling" of the transparent body, but keeping a top white fringe. It is proposed that this facies is similar to the gas curtain facies but with "visible" chemical and bacterial reactions in the superficial sediments. These reactions would consume gas coming from below and thus reduce the gas proportion in the top transparent fringe, resulting in a gas content that is too low to be observed on the Seistec profiles. This assumption seems to be confirmed by the low values of the signal amplitude. Thus, this facies would be a non- mature version of the gas curtain or blanket: a curtain/blanket facies in formation within unconsolidated sediments.

\section{Black shadow facies in Loch Creran}

This facies is characterised by

- a very high relative amplitude of the bottom reflector from- 60000 to 60000 (fig. 4C)

- a very high integrated instantaneous of the bottom reflector amplitude from 600 to 1800 (fig. 5)

- the occurrence of several well- marked multiples (fig. 5)

This facies remains restricted to the factory's vicinity. In the literature, similar strong sea floor reflectors and multiples have been related to waste material sometimes encountered in estuaries and harbours (Missiaen et al., 2002; McGee, 1989).

At Loch Creran, fish farm wastes are deposited in this area as confirmed by diving observations. This surface deposit generates gas directly by organic matter decomposition and this could explain the very high signal amplitudes and the ringing effect observed.

McGee (1989) observed that the waterlayer multiples are decaying more slowly over the waste material than the over the adjacent sea floor. This indicates that the reflectivity of the waste is greater than that of either the natural sediments or bed outcrop. That seems to confirm what we oberved on figure 2. But also the role of air caught in these fresh deposits and the contribution of the surface rugosity could be of some importance to explain the very high amplitude of the gas 
signature.

It has been shown by Anderson \& Hampton (1980a, b) and Tuffin et al., (2001) that gas bubbles in sediments are resonators and the seismic image strongly depends on the frequency spectrum of the source as well as on the physical bubbles parameters and bubble density. As we compare only Seistec subbottom profiles, we avoid any frequency misinterpretation caused by using different frequencies sources. Wilkens \& Richardson (1998) show that between $1.5 \mathrm{kHz}$ and $25 \mathrm{kHz}$, bubble resonance greatly affects seismic velocity and attenuation with the greatest reverberation occuring when the acoustic frequency matches the resonance of the bubbles. According to this diagram the resonance frequency window from $1 \mathrm{kHz}$ to $10 \mathrm{kHz}$, which corresponds to the Seistec equipment, covers bubble sizes from $0.6 \mathrm{~mm}$ to $6 \mathrm{~mm}$, the most frequent size of gas bubbles (in fact 0.5 to $5 \mathrm{~mm}$ ) reported in literature (Anderson \& Hampton, 1980a; Wilkens \& Richardson, 1998). This observation could explain why the Seistec system is so sensitive to the presence of gas.

Furthermore, the bubble characteristics (depending on the grain size of the particles) could remain a controlling factor for the appearance of the acoustic facies. This hypothesis needs to be further investigated by comparing cores sampled in different gas facies areas.

The Seistec profiles clearly indicate the gas originated from superficial sediments or from deeper layers in the subsurface. The superficial factory wastes facies (fig. 5) shows very strong integrated instantaneous amplitude values (> 1000) and a strong ringing; the succession of strong multiples appear as a black shadow on the Seistec profiles. The same observation was made for air caught in soft sands (Baltzer et al., 2003). Gas generated from deeper sediments is characterised by lower instantaneous amplitude values $(<300)$ and shows no ringing effects. Acoustic turbidity, gas curtains, gas blankets or white fringes facies are characterised by blank "shadows" directly underneath the gas signatures, due to the absorption of the signal.

\section{Conclusions}

The exceptional resolution of the Seistec boomer coupled with a good penetration allows a close observation of the different shapes and geometries of some typical seismic gas facies such as acoustic turbidity, gas curtains and blankets, and white fringes. Examples from abundant literature on shallow gas occurrence often remain largely based on qualitative observations. The Seistec data discussed here allowed us to present a more quantitative approach, based on signal 
analysis using software developed at IFREMER. These results linked to the environmental conditions could provide some clues about the gas source for the different seismic signatures observed.

The Leucate and Thau lagoons on one hand, and the Lochs Creran and Sunart $†$ on the other hand, show infilling of valleys or depressions. Acoustic turbidity, gas curtains and gas blankets constitute a similar expression of gas occurrence most likely related to biogenic gas (methane) originating from the deposition and maturation of organic material on the bottom of the depressions or valleys. The difference between the acoustic turbidity facies and the curtain or blanket facies is that the latter are generally sealed by a top layer or cap. These seismic facies therefore seems to represent the sub-surface footprints of buried channels and depressions.

The Loch Sunart†profile shows another example of infilling in its deeper parts. Associated facies shows gas curtain characteristics marked by a white fringe underlying the surface reflector. This facies most likely corresponds to a gas curtain in formation within unconsolidated sediments.

At Loch Creran a profile shows an example of fish farm wastes. In this surface†deposit facies, gas is generated directly at the sediment surface by the organic matter decomposition. The decaying waste accounts for the very strong signal amplitude†and the ringing effect observed. The role of air caught in these deposits and the contribution of the roughness of the deposit may play an additional role in the abnormal amplitude values of the gas signature.

The broad frequency range of the Seistec boomer has proved to be extremely sensitive for gas detection. Combined with signal amplitude analysis, this has allowed discrimination of gas origin from superficial sediments (the fish farm wastes case, amplitude > 1000) or from deeper layers in the sedimentary column (infillings of valleys, amplitude < 300).

\section{Aknowledgements}

The writers are especially grateful to the different people who participated in the Seistec surveys: F. Lelong, J.M. Rousset, P. Bretel , B. Austin, J. \& J-C Rousset, R. Certain. Special thanks is expressed to Peter Simpkin for his help with this paper. 


\section{References:}

Anderson AL and Hampton LD (1980a) Acoustics of gas bearing sediments. Background. Journal Acoustical Soc. Am. 67 /6: 1865-1889.

Anderson AL and Hampton LD (1980b) Acoustics of gas bearing sediments. II. Measurements and models. Journal Acoustical Soc. Am. 67/6: 1865-1889.

Baltzer A, StÈpanian A, Owono J and Tessier B (2003) Identification des sables vacuolaires ¥ terre et en mer. Revue FranÁaise de GÈnie Civil- RFGC 9:1139-1149

Davis AM (1992) Shallow gas † an overview. Continental Shelf Research. 2/10: 1077-1079.

Emery KO and Hoggan D (1958) Gases in marine sediments.AAPG Bulletin 42†: 2174-2188.

Hovland M and Judd AG (1988.) Seabed pockmarks and seepages, impact on geology. Biology and the Marine Environment. (Ed ) Graham \& Trotman, London, 1988.

Garcia-Gil S, Vilas F and Garcia-Garcia A (2002) Shallow gas features in incised-valley fills Ria de Vigo, NW Spain†: a case study. Continental Shelf Research 22: 2303-2315.

Gorgas TJ, Kim GY, Park SC, Wilkens RH, Kim DC, Lee GH and Seo YK (2003) Evidence for gassy sediments on the inner shelf of SE Korea from geoacoustic properties. Continental Shelf Research 23: 821-834.

Mc Gee TM (1991) Seismic reverberation and the remote estimation of properties of underwater soils. International Journal of Imaging Systems and Technology†3: 40-57.

Missiaen T, Murphy S, Loncke L and Henriet JP (2002) Very high resolution seismic mapping of shallow gas in the Belgian coastal zone. Continental Shelf Research†22: 2303-2315.

Mosher DC and Simpkin, PG (1999) Status and Trends of Marine High-Resolution Seismic Reflection Profiling: Data Acquisition. Geoscience Canada. 26, 22 pages.

NouzÈ H and Baltzer A (2003) Shallow bottom-simulating reflectors on the Angola 
margin, in relation with gas and gas hydrate in the sediments. In: Van Rensbergen P, Hillis RR, Maltman AJ, Morley CK (eds) Special publication for the geological Society of London about subsurface sediment mobilization From Subsurface mobilization, vol 216 pp 191-206.

Simpkin P and Davis M (1993) For Seismic profiling in very shallow water, a novel receiver. Sea Technology 34: 5 p.

Taylor DI (1992) Nearshore shallow gas around the U.K. coast. Continental Shelf Research 12 / N_ 10: 1135-1143.

Tuffin MDJ, Best AL, Dix JK and Bull JM (2001) Temporal variability of P-Wave attenuation due to gas bubbles in a marine sediment. In: Acoustic Oceanography, T. G. Leighton et al., Proc. Institute of Acoustics 23 (2), pp 291-298.

Wever TF and Fiedler HM (1995) Variability of acoustic in Eckernforde Bay (southwest Baltic Sea) related to the annual temperature cycle. Marine Geology 125: 21-27.

Wilkens RH and Richardson MD (1998) The influence of gas bubbles on sediment acoustic properties: in situ, laboratory and theoretical results from Eckernforde Bay, Baltic sea.

Continental Shelf Research 18: 1859-1892. 

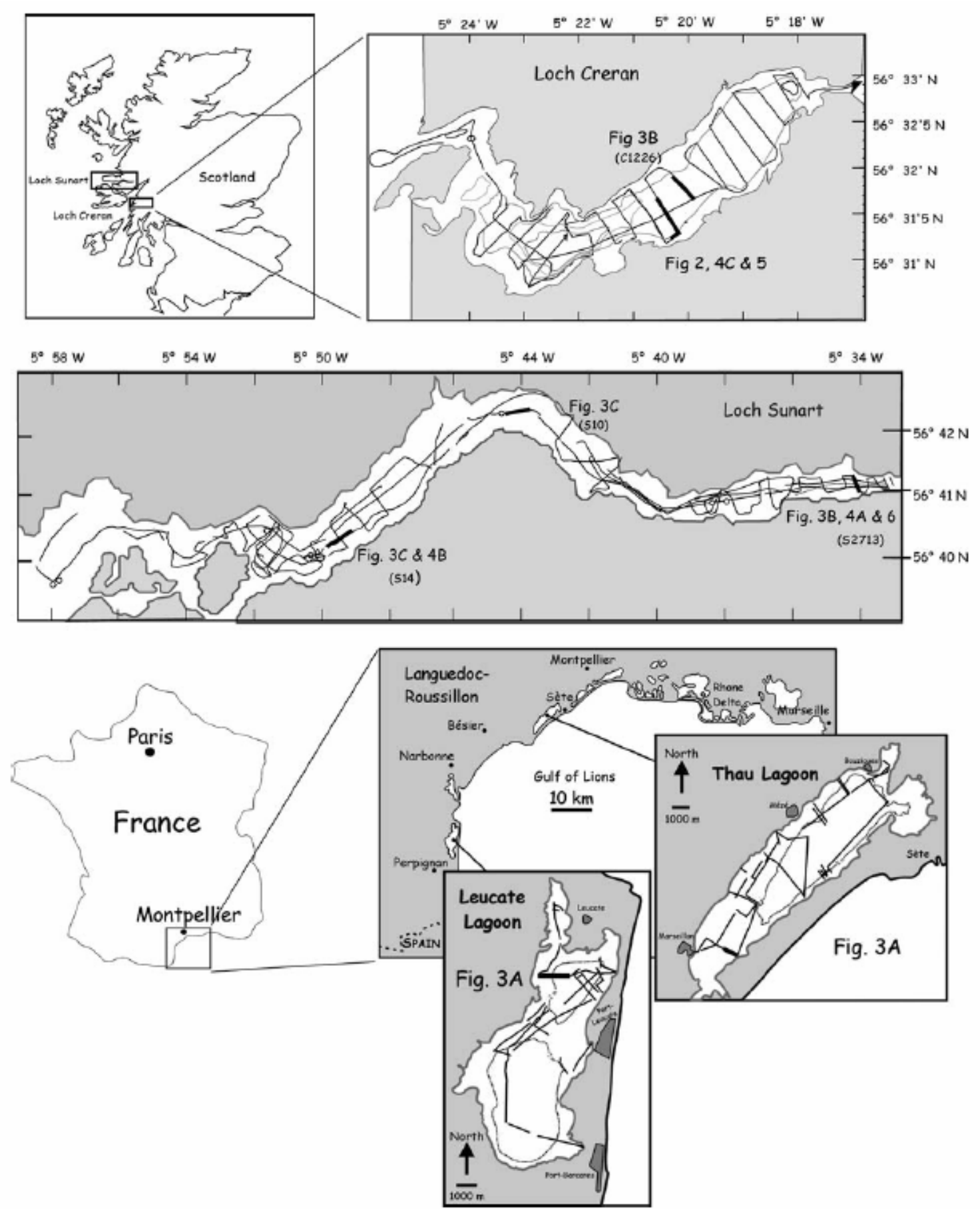

Figure 1. Location of the different study areas and Seistec profiles acquired in Scotland (Loch Sunart and Loch Creran) and France (Lake Leucate and Thau Lagoon) 




Figure 2. Seistec profile 10 bis shows the succession, from West to East, of different characteristic gas facies in shallow sediments: black shadow dur to organic wastes from a fish farm factory, a gas curtain and a gas blanket with perhaps a gas plume in the water. This profile was acquired in Loch Creran (West coast of Scotland) .

(a)
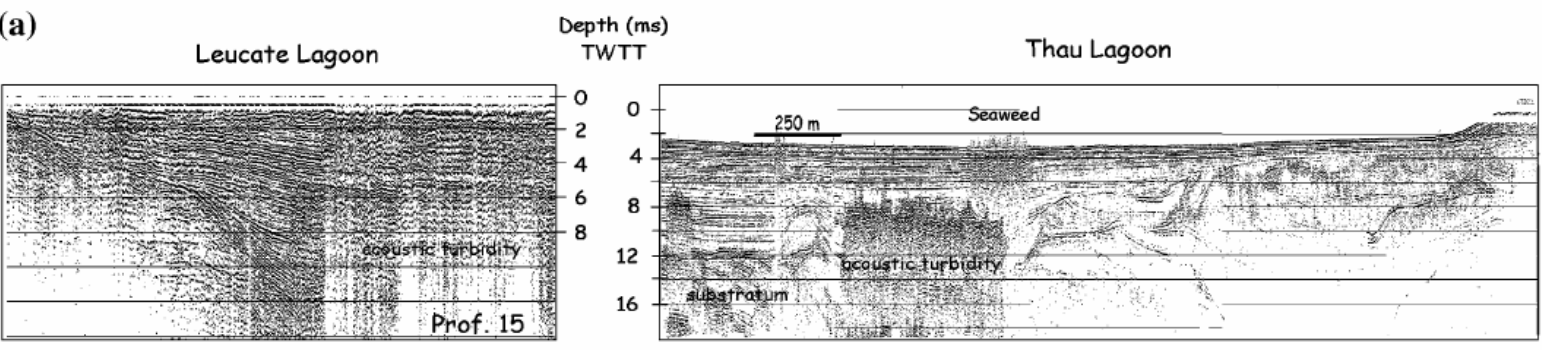

(b)

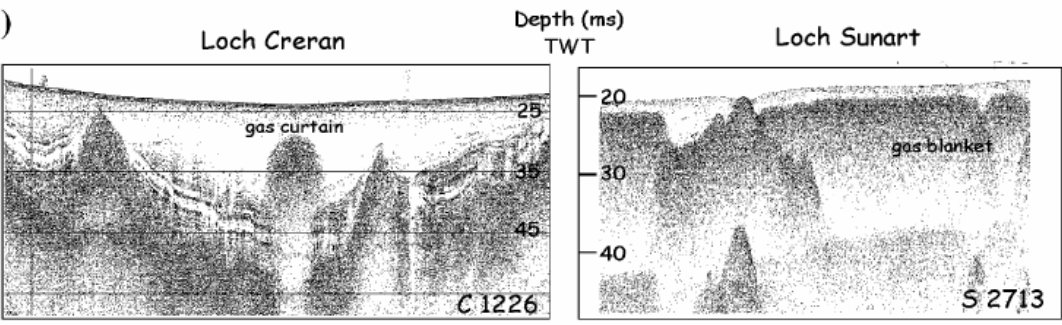

(c)

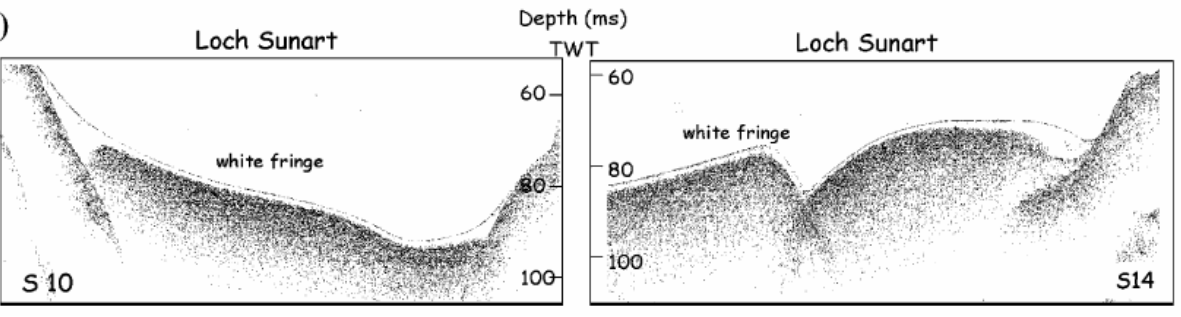

Figure 3. Different Seistec profiles showing three characteristical gas facies. 3A) Acoustic turbidity facies facies in infillings of depressions in Leucate and Thau lagoons. 3B) Gas curtain facies in Loch Creran which coincides with the deepest part of the depression, and gas blanket (similar facies to curtain but with a greater extension) in Loch Sunart. 3C) White fringe facies, revealed by two profiles acquired in Loch Sunart. This facies is characterised by a white or transparent fringe, keeping the same thickness (around $1.3 \mathrm{~m}$ ) all along the profile whatever the water depth and topography, except at the contact with the valley edges. 
(a) Loch Sunart
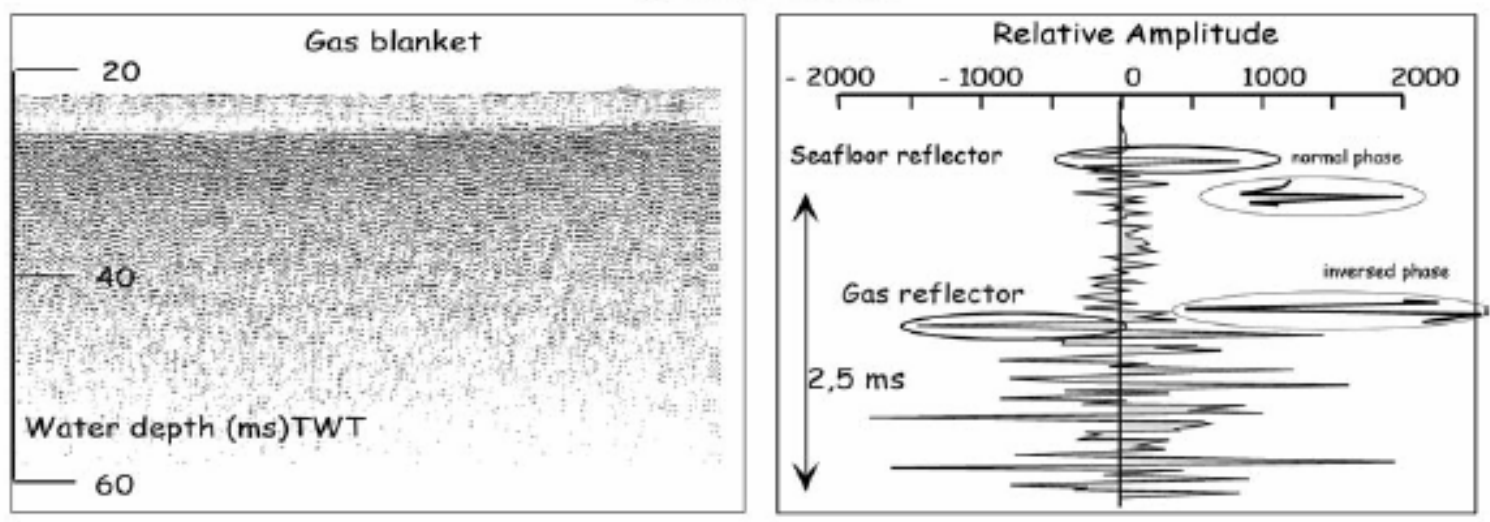

(b) Loch Sunart
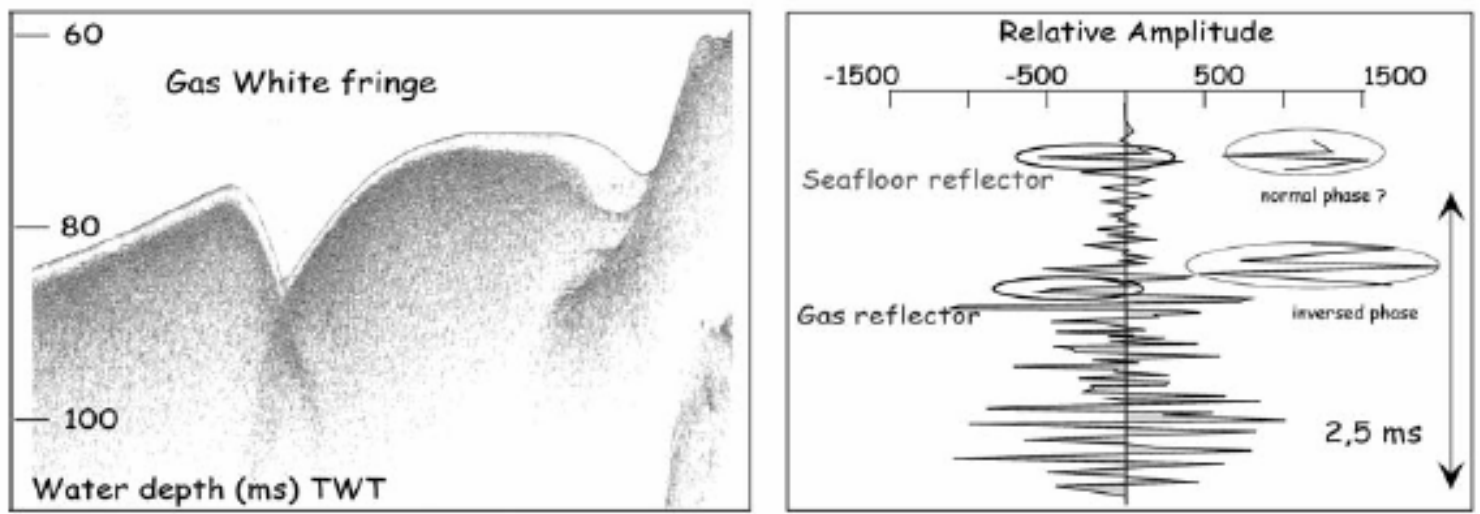

(c) Loch Creran
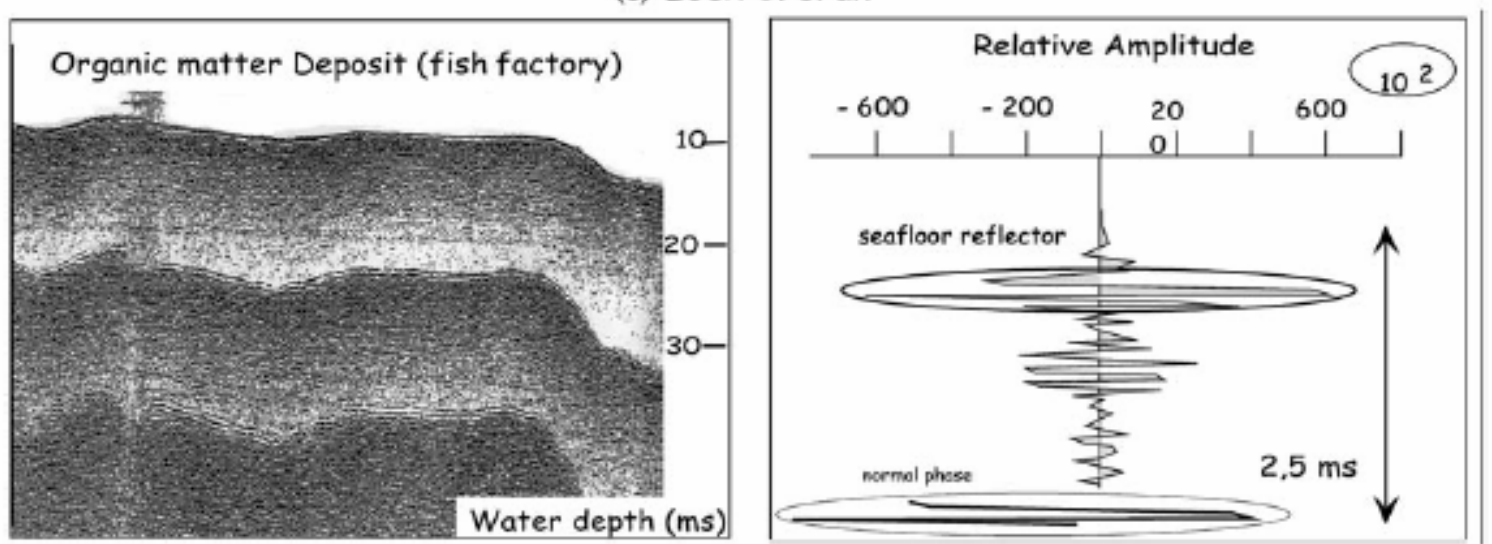

Figure 4. Seismic polarisation analysis of three different cases of gas facies selected on Seistec sections. Single shot signal is shown on the right. Amplitude values shown are relative amplitudes. 4A) Profile acquired in Loch Sunart presenting a typical gas blanket facies. The signal polarisation analysis shows the signature of the seafloor reflector with a positive high first peak of the amplitude (1000), and the gas reflector showing a negative peak of the amplitude (-1500) with a phase inversion. 4B) Profile acquired in Loch Sunart presenting a very particular gas facies characterised by acoustic turbidity topped by a transparent white fringe. The amplitude of the seafloor reflector is negative (-500) and the amplitude of the gas reflector varies from - 1000 to 1000 . The signal polarisation analysis cannot indicate a clear proof of a phase inversion. 4C) A section of profile 10 (fig.2) acquired in loch Creran corresponding to the fish factory waste site. Two multiples occur, very well marked, masking all other sub reflectors. The amplitude of the bottom reflector reaches the huge value of 60000 ! 


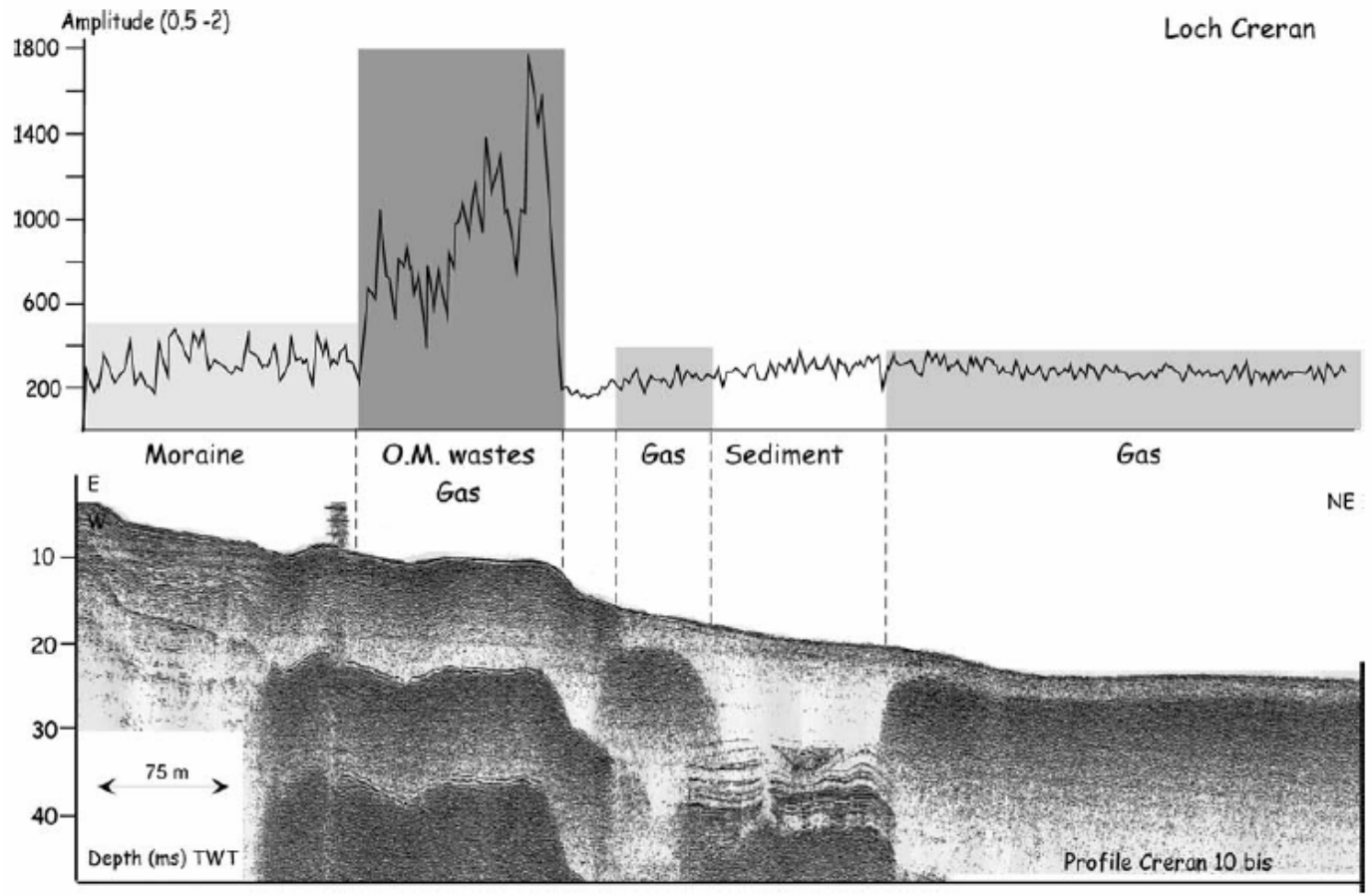

Figure 5. Seismic integrated amplitude analysis (instantaneous amplitude) of Seistec data acquired in Loch Creran. This amplitude analysis is realised on a time window (between 0.5 and - $2 \mathrm{~ms}$ ) for all the shots along the profile. Note the extreme high amplitude values (from 1000 to 1800) of the organic wastes from the fish farm factory compared with the other values, including gassy sediments (around 300). Due to the scale, differentiation between the gas and moraine facies is not so clear.

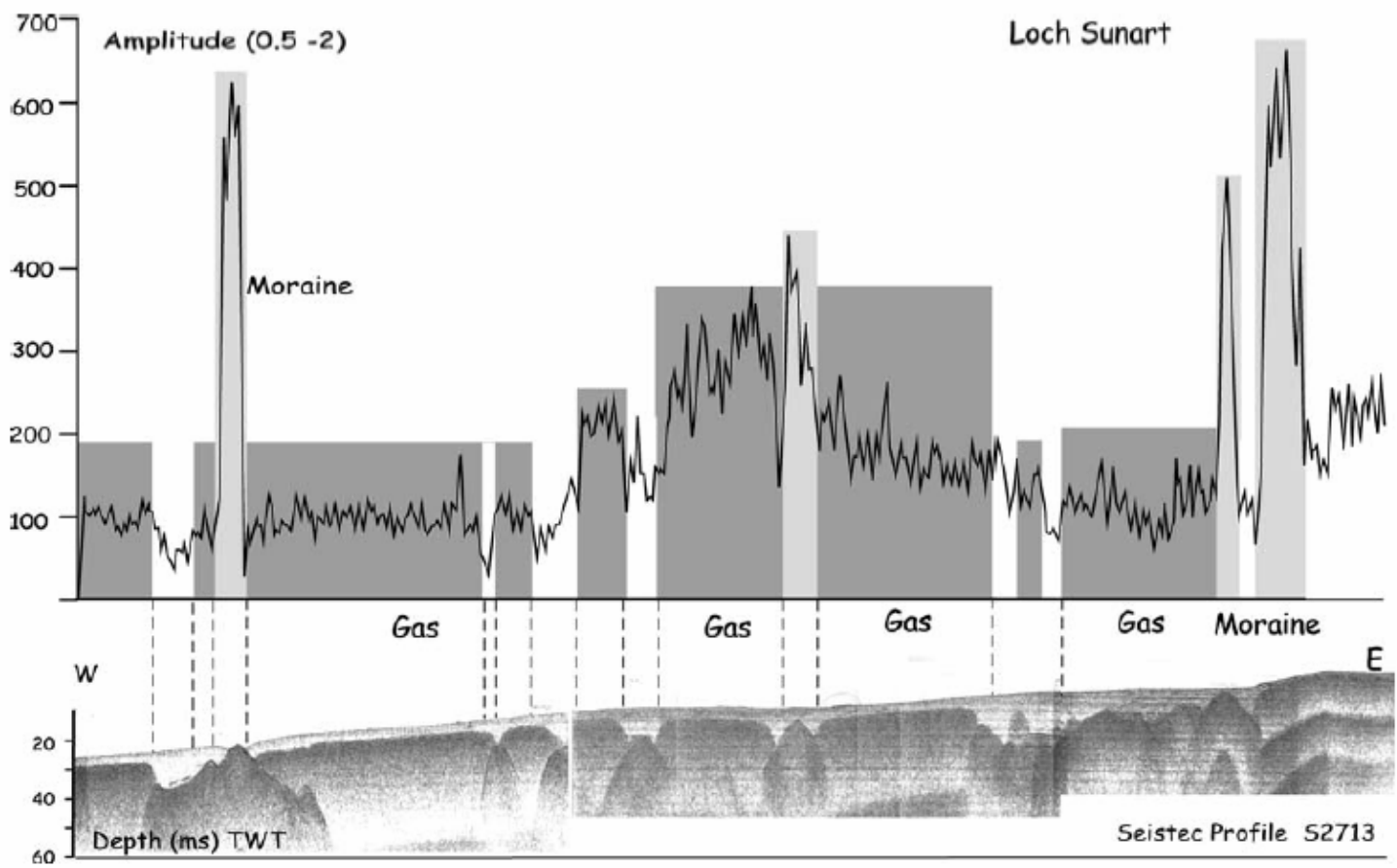

Figure 6. Seismic integrated amplitude analysis (instantaneous amplitude) of Seistec data acquired in Loch Sunart. This amplitude analysis is realised on a time window (between 0.5 and - $2 \mathrm{~ms}$ ) for all the shots along the profile. The signal analysis allowed to easily differentiate morainal facies (integrated amplitude values from 600 to 700) from gas blanket facies (amplitude values from 100 to 300). 